\title{
Knowledge Integration and Open Innovation in the Brazilian Cosmetics Industry
}

\author{
Kleber Luís Celadon'
}

\begin{abstract}
This article is based on a thesis that examined open innovation in the Brazilian cosmetics sector and its relationship with knowledge integration, comparing less open and more open firms. The ability to integrate knowledge is related to competitive advantage, and this study sheds light onto Ol at each different firm. The main findings show that, different levels of openness in innovation, demand firm-specific mechanism for KI. Also, openness increases complexity in management. The understanding of how firms select their knowledge for appropriation and differentiation is also considered. The Brazilian cosmetics market was chosen because it occupies the 3rd position in the world's ranking and this industry is under researched. A cross-case comparison is used.
\end{abstract}

Keywords: open innovation; knowledge integration; cosmetics; cross-case comparison.

I CENTRIM, University of Brighton, I54-I 55 Edward Street, Brighton, BN2 0JG, United Kingdom.

Phone: +44 I 273 608844; e-mail: K.L.Celadon@brighton.ac.uk

ISSN: 07 I8-2724. (http://www.jotmi.org)

Journal of Technology Management \& Innovation (c) Universidad Alberto Hurtado, Facultad de Economía y Negocios. 


\section{Introduction}

Making use of external and internal ideas to advance knowledge is claimed to bring more competitiveness for companies in general. The inflow and outflow of knowledge, which are part of this process, involve practices that should encourage participants to explore a wide range of innovation opportunities through multiple channels (West \& Gallagher, 2006). Several authors (Acha, 2006; Celadon, 2007; H. Chesbrough, 2003b;W. Cohen \& Levinthal, 1990; Easterby-Smith \& Prieto, 2008; Howells, 1996; I. a. T. Nonaka, H., 1995; Polanyi, 1958) affirm that innovation processes can no longer be limited to local or internal know-how, but needs to focus more on professionals that can maximize the effectiveness of innovation, as well as finding alternate sources such as markets or spillovers. An example of that in the cosmetics sector is the search for special and unique knowledge (i.e. fragrance experts) that sometimes is available in another country. Also, emerging markets can be explored according to changes in socio-economic conjectures. This implies interaction and integration of knowledge, suggesting a relationship with another concept, that is, Knowledge Integration, which has been explained as a learning process within organizations and, therefore, has been seen as a critical process for understanding firm's competitiveness. It depends on people's attitudes towards learning, it varies in scope (the greater the harder for competitor to replicate) and it can be more or less flexible in relation to the capacity an organization has to build one innovation initiative on the top of another (R. M. Grant, 1996a; Huang \& Newell, 2003).

Both Open Innovation and Knowledge Integration have complementarities, as well as overlapping dimensions, and have not been compared in previous studies. So, these concepts can be also antagonistic, and an investigation is necessary to study this relationship, taking into consideration that strategic shaping might influence organizational forms and practices (Penrose, 1959), as well as the important dimensions of innovation such as offerings, presence, customers and processes (Sawhney, Wolcott, \& Arroniz, 2006), preferably in low-medium technology industries which are under researched to present. The economic context suggests firms are encouraged to implement open innovation mechanisms and knowledge integration to be successful. So, this research aims to study how firms deal with these concepts in practice. Brazil's economy is still largely support by low and medium-to-low technology firms. Therefore, studying these types of firms, and not only high-tech firms, is essential to this country's future economic wellbeing.

A cross-comparison has been carried out on a specific sector, the cosmetics, toiletry and perfumery sector, and referred to only as the cosmetics sector/industry from this point onwards.

\section{Research questions}

This research addresses two main propositions:

I. Knowledge integration is both an activity and a capability for industrial innovation and competitiveness, because it is responsible for optimizing knowledge exchanged from professionals of different backgrounds, and making use of this knowledge to create value for the organizations. As the cosmetics industry involves a substantial level of knowledge exchange, explicit and tacit, integrating mechanisms are most important to maintain the effectiveness of innovation policies.

2. Open innovation is likely to be an important influence on knowledge integration because the use of outside resources is likely to increase the levels of complexity for innovation. It also involves even more different people (cultures and managerial models) as much as different perceptions from professionals involved, meaning a greater challenge to management.

These propositions suggest the following research question: Under different conditions of openness, how do the mechanisms and practices of knowledge integration differ, and how does this influence innovation?

\section{Methodology}

The relationship between the two concepts is directly related, that is, the more intensity employed in one concept, the more will be needed in the other one. Ol practices imply higher complexity in $\mathrm{KI}$. 


\begin{tabular}{|c|c|c|}
\hline \multicolumn{3}{|c|}{$\begin{array}{c}\text { The Relationship Between The Two Concepts } \\
\text { Open Innovation and Knowledge Integration }\end{array}$} \\
\hline & OPEN INNOVATION & KNOWLEDGE INTEGRATION \\
\hline 1 & Exploitative (Murmann) $x$ Explorative $(\mathrm{XR})$ & $\begin{array}{l}\text { Combination of skills of individuals to generate } \\
\text { knowledge }\end{array}$ \\
\hline $\begin{array}{l}\text { Literature } \\
\text { Review }\end{array}$ & (Brady \& Davies, 2004; H. Chesbrough, 2003b) & (Okhuysen \& Eisenhardt, 2002; Tell, 20I I) \\
\hline Synthesis & \multicolumn{2}{|c|}{$\begin{array}{l}\text { Ol proposes that firms should exploit existing knowledge while explore knowledge available global- } \\
\text { ly. This demands a combination of skills of individuals for both actions in order to optimize its results. }\end{array}$} \\
\hline 2 & $\begin{array}{l}\text { Focus on Internal Knowledge }(\mathrm{IN}) \times \text { Combina- } \\
\text { tion of Int }+ \text { Ext Knowledge }(\mathrm{CB})\end{array}$ & Integration of new and existing knowledge \\
\hline $\begin{array}{l}\text { Literature } \\
\text { Review }\end{array}$ & $\begin{array}{l}\text { (H. a.V. Chesbrough,Wim and West, Joel, 2006c; } \\
\text { Henry William Chesbrough, 2003a; Gassmann, } \\
\text { 2006; Gassmann \& Enkel, 2004) }\end{array}$ & $\begin{array}{l}\text { (Blackler, 2002; Hislop, Newell, Scarbrough, \& } \\
\text { Swan, 2000; I. a.T. Nonaka, H., 1995; Yang, 2005) }\end{array}$ \\
\hline Synthesis & \multicolumn{2}{|c|}{$\begin{array}{l}\text { Even though semantics can differ in the two proposals, the main idea here is to combine and inte- } \\
\text { grate knowledge (internal and external) }\end{array}$} \\
\hline 3 & $\begin{array}{l}\text { Less (LE) or More (MO) Market oriented deci- } \\
\text { sion making processes }\end{array}$ & Integration of existing (market) knowledge \\
\hline $\begin{array}{l}\text { Literature } \\
\text { Review }\end{array}$ & $\begin{array}{l}\text { (Clark \& Wheelwright, 1993; Hislop, et al., 2000; } \\
\text { Shibata, Tse,Vertinsky, \& Wehrung, 1991; Tushman \& } \\
\text { Scanlan, 1981) }\end{array}$ & $\begin{array}{l}\text { (Amin \& Cohendet, 2004; Bengtsson, Niss, } \\
\text { \& von Haartman, 2008; Chiva, 2005; Criscuolo } \\
\text { \& Nesta, 2008; DeFillippi, 2006; Dosi, Faillo, \& } \\
\text { Marengo, 2008; Dougherty, 1992; Easterby-Smith } \\
\text { \& Prieto, 2008; Howells, 1996; I. a. T. Nonaka, Da- } \\
\text { vid, 200I; I. a.T. Nonaka, H., I995; Polanyi, I958; } \\
\text { Tell, 20I I) }\end{array}$ \\
\hline Synthesis & \multicolumn{2}{|c|}{$\begin{array}{l}\text { These are two complementary ideas which are interdependent. If, for example, decision is more } \\
\text { oriented on market, integration is also oriented to market and vice-versa. }\end{array}$} \\
\hline 4 & Dealing with Tacit knowledge & $\begin{array}{l}\text { Knowledge and skills to solve problems (peo- } \\
\text { ple's qualification and experience) }\end{array}$ \\
\hline $\begin{array}{l}\text { Literature } \\
\text { Review }\end{array}$ & $\begin{array}{l}\text { (H. Chesbrough \& Crowther, 2006; Etzioni, } \\
\text { 1996; Howells, I996; Lam, 2000; Leonard \& Sensip- } \\
\text { er, I998; Polanyi, 1967; Roberts, 2006; Scott, Stuart, } \\
\text { Stephanie, \& Robert, 2003) }\end{array}$ & $\begin{array}{l}\text { (Amin \& Cohendet, 2004; Bengtsson, et al., } \\
\text { 2008; Chiva, 2005; S. I. Cohen \& Allen, 1969; } \\
\text { Criscuolo \& Nesta, 2008; DeFillippi, 2006; Dosi, et } \\
\text { al., 2008; Dougherty, I992; Easterby-Smith \& Prie- } \\
\text { to, 2008; Robert M. Grant, I996b, I 997; Howells, } \\
\text { 1996; Leonard-Barton, I992; I. a. T. Nonaka, David, } \\
\text { 200 I; I. a. T. Nonaka, H., 1995; Polanyi, I958; Tell, } \\
\text { 20I I) }\end{array}$ \\
\hline
\end{tabular}




\begin{tabular}{|c|c|c|}
\hline Synthesis & \multicolumn{2}{|c|}{$\begin{array}{l}\text { While } \mathrm{KI} \text { focuses more on problem solving in this particular item, OI suggests that dealing with tacit } \\
\text { knowledge supports innovative practices. Tacit knowledge is embedded in people's experience and } \\
\text { complements problem solving. }\end{array}$} \\
\hline 5 & $\begin{array}{l}\text { Weak ties (Hawkins, Best, \& Coney) } \times \text { Strong ties } \\
\text { (ST) }\end{array}$ & Technical systems (Machinery, Labs) \\
\hline $\begin{array}{l}\text { Literature } \\
\text { Review }\end{array}$ & (Granovetter, 1973) & $\begin{array}{l}\text { (S. I. Cohen \& Allen, 1969; Leonard-Barton, } \\
\text { 1992) }\end{array}$ \\
\hline Synthesis & \multicolumn{2}{|c|}{$\begin{array}{l}\text { Ties are also determined by technical systems because it implies relationships with suppliers, con- } \\
\text { sumers and other stakeholders. In this item, these ties have been framed by the mentioned technical } \\
\text { systems for the analysis. }\end{array}$} \\
\hline 6 & Network at individual level $x$ Firm level & $\begin{array}{l}\text { Integrative Capabilities (Absorptive capacity, } \\
\text { ability to share knowledge) }\end{array}$ \\
\hline $\begin{array}{l}\text { Literature } \\
\text { Review }\end{array}$ & $\begin{array}{l}\text { (Henry William Chesbrough, 2007; S. D. N. Cook } \\
\text { \& Brown, 1999; Gann, 2005; Rothwell, 1994; Si- } \\
\text { moes-Brown, 2008) }\end{array}$ & $\begin{array}{l}\text { (Cockburn \& Henderson, 1998;W. Cohen \& } \\
\text { Levinthal, I990; Lane \& Lubatkin, 1998;Vanhaver- } \\
\text { beke, Cloodt, \& van de Vrande, 2007;Volberda, } \\
\text { Foss, \& Lyles, 2010; Zahra \& George, 2002) }\end{array}$ \\
\hline Synthesis & \multicolumn{2}{|c|}{$\begin{array}{l}\text { The various combinations are: Network at individual level with high or low intensity of absorptive } \\
\text { capacity - and - Network at firm level with high or low intensity of absorptive capacity (으 both }) \text {. Net- } \\
\text { works in this item are the basis of knowledge sharing. }\end{array}$} \\
\hline 7 & $\begin{array}{l}\text { Reorganization of existing structures } \times \text { Creation of } \\
\text { multiple ad hoc structures }\end{array}$ & $\begin{array}{l}\text { Dynamic Capabilities (ability to change accord- } \\
\text { ing to market or other demands) }\end{array}$ \\
\hline $\begin{array}{l}\text { Literature } \\
\text { Review }\end{array}$ & $\begin{array}{l}\text { (Dosi, et al., 2008; Granstrand, Bohlin, Oskarsson, } \\
\text { \& Sjöberg, 1992; Lane \& Lubatkin, 1998; Littler, } \\
\text { Wiesner, \& Dunford, 2003; Okhuysen \& Eisenhardt, } \\
\text { 2002) }\end{array}$ & $\begin{array}{l}\text { (Easterby-Smith \& Prieto, 2008; Gulati, Nohria, } \\
\text { \& Zaheer, 2000; McGuinness, 2008; Teece \& Pisa- } \\
\text { no, 1994; Teece, Pisano, \& Shuen, 1997) }\end{array}$ \\
\hline Synthesis & \multicolumn{2}{|c|}{$\begin{array}{l}\text { Some reorganization or ad hoc structures demand dynamic capabilities. So, the relationship of OI } \\
\text { and } \mathrm{KI} \text { in this case depends on the intensity of each item applied by each firm. }\end{array}$} \\
\hline 8 & $\begin{array}{l}\text { Informal } \times \text { Formal Evaluation Process (x Transition } \\
\text { from informal to formal) }\end{array}$ & $\begin{array}{l}\text { Implicit/Social or Collective Knowledge (facil- } \\
\text { itates the creation of products i.e. regional usage } \\
\text { of cosmetics, culture, etc) }\end{array}$ \\
\hline $\begin{array}{l}\text { Literature } \\
\text { Review }\end{array}$ & (Littler, et al., 2003) & $\begin{array}{l}\text { (Hatchuel, Le Masson, \& Benoît, 2002; Lehrer, } \\
\text { 1987; Scott, et al., 2003;Tushman \& Scanlan, I98I) }\end{array}$ \\
\hline Synthesis & \multicolumn{2}{|c|}{$\begin{array}{l}\text { Firms tend to move from informality to formality during their development. This might include the } \\
\text { creation of systems that collect social knowledge by establishing interfaces with users, consumers and } \\
\text { the community. }\end{array}$} \\
\hline 9 & Accelerate Innovation and/or Expand Market & Organizational Structure (vertical $x$ horizontal) \\
\hline $\begin{array}{l}\text { Literature } \\
\text { Review }\end{array}$ & $\begin{array}{l}\text { (Christensen, Olesen, \& Kjær, 2005; Laursen \& Salt- } \\
\text { er, 2006; von Hippel, 1988, 2005; von Hippel, 2007) }\end{array}$ & $\begin{array}{l}\text { (Ahuja, 2000; Allio, 2005; Dosi, et al., 2008; Ha- } \\
\text { vens \& Knapp, 1999; Lam, 2000; Lane \& Lubatkin, } \\
\text { 1998; Lindegaard, 20I0; Okhuysen \& Eisenhardt, } \\
\text { 2002; Selznick, I957;Tushman, 1977) }\end{array}$ \\
\hline Synthesis & \multicolumn{2}{|c|}{$\begin{array}{l}\text { This item was created to observe the relationship between Internal x External Market acceleration } \\
\text { in comparison to Vertical } \times \text { Horizontal structures. }\end{array}$} \\
\hline 10 & Rewarding system in place & Managerial Systems (i.e. leadership style) \\
\hline
\end{tabular}




\begin{tabular}{|c|c|c|}
\hline $\begin{array}{l}\text { Literature } \\
\text { Review }\end{array}$ & $\begin{array}{l}\text { (Henry William Chesbrough, 2003a; Murray \& } \\
\text { O'Mahony, 2007) }\end{array}$ & $\begin{array}{l}\text { (Allio, 2005; Havens \& Knapp, 1999; Lindegaard, } \\
\text { 2010; Selznick, 1957) }\end{array}$ \\
\hline Synthesis & \multicolumn{2}{|c|}{$\begin{array}{l}\text { Rewarding system is part of managerial system that can be used differently according to leadership } \\
\text { styles. }\end{array}$} \\
\hline II & $\begin{array}{l}\text { Platform onto which people can add their ideas } \\
\text { and contributions }\end{array}$ & Values and Norms (Culture) \\
\hline $\begin{array}{l}\text { Literature } \\
\text { Review }\end{array}$ & (Meyer \& Mugge, 200I; Sawhney, et al., 2006) & $\begin{array}{l}\text { (S. D. N. a. D.Y. Cook, 1993; Ernst \& Kohn, } \\
\text { 2007; Gherardi, 2002; Pilania, 2006; Sackmann, } \\
\text { I992; Sahota \& Lemon, 2004; Schein \& 1993; Shi- } \\
\text { bata, et al., I99I;Tushman \& Scanlan, I98I) }\end{array}$ \\
\hline Synthesis & \multicolumn{2}{|c|}{$\begin{array}{l}\text { In this item culture is seen as the foundation for contribution systems where people can add their } \\
\text { ideas. }\end{array}$} \\
\hline 12 & Breadth ( $\mathrm{n}$ of sources) $\times$ Depth (importance) & $\begin{array}{l}\text { Invisible Assets (i.e. people's perception of a } \\
\text { firm as a 'green' company) }\end{array}$ \\
\hline $\begin{array}{l}\text { Literature } \\
\text { Review }\end{array}$ & $\begin{array}{l}\text { (Dougherty, 1992; Laursen \& Salter, 2005; Laurs- } \\
\text { en \& Salter, 2006) }\end{array}$ & $\begin{array}{l}\text { (Blackler, 2002; Hawkins, et al., I995; Rindova \& } \\
\text { Petkova, 2007; Tell, 20I I) }\end{array}$ \\
\hline Synthesis & \multicolumn{2}{|c|}{$\begin{array}{l}\text { The way that firms deal with brand, R\&D concessions, licensing, patents, goodwill, and people's } \\
\text { perceptions in general, either by making arrangements with several of them (breadth) or dealing more } \\
\text { specifically with few of them more profoundly (depth). }\end{array}$} \\
\hline 13 & Formal X Informal Relationships & $\begin{array}{l}\text { Organizational reaction to internal and exter- } \\
\text { nal contingencies }\end{array}$ \\
\hline $\begin{array}{l}\text { Literature } \\
\text { Review }\end{array}$ & $\begin{array}{l}\text { (Bessant \& Tsekouras, 200I; Bruner, 1990; Mow- } \\
\text { ery, 1982; Perkmann \& Walsh, 2007; Polanyi, 1958; } \\
\text { Powell, Koput, \& Smith-Doerr, 1996) }\end{array}$ & $\begin{array}{l}\text { (Bengtsson, Bergek, Berggren, \& Söderlund, } \\
\text { 2009; Bengtsson, et al., 2008; Carlile, 2002; Cassi- } \\
\text { man \& Veugelers, 2006; Chiva, 2005; Criscuolo \& } \\
\text { Nesta, 2008; Enberg, 2007; Fernandez-Breis, Cas- } \\
\text { tellanos-Nieves, \& Valencia-Garcia, 2009; Grans- } \\
\text { trand, et al., I992; R. M. Grant, I996a; Gulati, et al., } \\
\text { 2000; Huang \& Newell, 2003; Kodama, 2009; Lane } \\
\text { \& Lubatkin, I998; Laursen \& Salter, 2005; Næves- } \\
\text { tad, 2008; Okhuysen \& Eisenhardt, 2002; Pisano, } \\
\text { I994; Ravasi \& Verona, 200I; Söderlund, 20I0; Tell, } \\
\text { 20I I;Tsekouras, 2006; Tushman \& Scanlan, I98I; } \\
\text { Wallin \& Von Krogh, 20I0; Yang, 2005) }\end{array}$ \\
\hline Synthesis & \multicolumn{2}{|c|}{$\begin{array}{l}\text { The type of relationship (formal or informal) might determine different ways of reaction to internal } \\
\text { and external contingencies }\end{array}$} \\
\hline 14 & User Innovation & External Integration (suppliers, researchers) \\
\hline $\begin{array}{l}\text { Literature } \\
\text { Review }\end{array}$ & $\begin{array}{l}\text { (Flowers, 2007, 2008; Flowers \& Henwood, } \\
\text { 20I0; Hienerth, 2006; von Hippel, 1986; von Hippel, } \\
\text { 1988, 2005; von Hippel, 2007) }\end{array}$ & $\begin{array}{l}\text { (Bengtsson, et al., 2009; Bengtsson, et al., 2008; } \\
\text { Carlile, 2002; Chiva, 2005; Criscuolo \& Nesta, } \\
\text { 2008; Enberg, 2007; Fernandez-Breis, et al., 2009; } \\
\text { R. M. Grant, I 996a; Huang \& Newell, 2003; Koda- } \\
\text { ma, 2009; Okhuysen \& Eisenhardt, 2002; Pisano, } \\
\text { I994; Ravasi \& Verona, 200 I; Söderlund, 20 I0; Tell, } \\
\text { 20I I;Tsekouras, 2006; Wallin \& Von Krogh, 20I0; } \\
\text { Yang, 2005) }\end{array}$ \\
\hline
\end{tabular}




\begin{tabular}{|c|c|c|}
\hline Synthesis & \multicolumn{2}{|c|}{$\begin{array}{l}\text { This item focuses on suppliers, researchers and other participants observing their contribution to } \\
\text { innovation as well as users that make inputs to innovation. User innovation is also an external source } \\
\text { for integration }\end{array}$} \\
\hline 15 & Use of external network community & $\begin{array}{l}\text { Internal (cross-functional, individual prob- } \\
\text { lem-solving, spanning boundaries) }\end{array}$ \\
\hline $\begin{array}{l}\text { Literature } \\
\text { Review }\end{array}$ & $\begin{array}{l}\text { (Bessant \& Tsekouras, 200I; Birkinshaw, Bessant, } \\
\text { \& Delbridge, 2007; Gulati, et al., 2000) }\end{array}$ & $\begin{array}{l}\text { (Andersson, Holm, \& Johanson, 2006; Carlile, } \\
\text { 2002; Dosi, et al., 2008; Huang \& Newell, 2003; } \\
\text { Leonard \& Sensiper, I998; Mintzberg, Jorgensen, } \\
\text { Dougherty, \& Westley, 1996; Okhuysen \& Eisen- } \\
\text { hardt, 2002; Tushman, 1977; Tushman \& Scanlan, } \\
\text { 1981; Zarifian, 1996) }\end{array}$ \\
\hline Synthesis & \multicolumn{2}{|c|}{$\begin{array}{l}\text { The use of external communities might impact on internal mechanisms for the integration of knowl- } \\
\text { edge. Some firms can do either or both. }\end{array}$} \\
\hline 16 & Communities of Practice & Transfer of knowledge \\
\hline $\begin{array}{l}\text { Literature } \\
\text { Review }\end{array}$ & $\begin{array}{l}\text { (Brown \& Duguid, I991; Lane \& Lubatkin, 1998; } \\
\text { Powell, et al., I996; Roberts, 2006; Wenger, 1998) }\end{array}$ & $\begin{array}{l}\text { (Carlile, 2002; Easterby-Smith, A. Lyles, \& Tsang, } \\
\text { 2008; Kogut, 2000; Ringberg \& Reihlen, 2008; } \\
\text { Scott, et al., 2003; Szulanski, 2000; Tushman \& } \\
\text { Scanlan, 198I;Watson \& Hewett, 2006) }\end{array}$ \\
\hline Synthesis & \multicolumn{2}{|c|}{ One way of transferring knowledge is by contributing via communities of practice. } \\
\hline 17 & Swift trust in collaboration & Communication between specialists \\
\hline $\begin{array}{l}\text { Literature } \\
\text { Review }\end{array}$ & (Meyerson,Weick, \& Kramer, 1996) & (Carlile, 2002; Tushman, 1977; Zarifian, 1996) \\
\hline Synthesis & \multicolumn{2}{|c|}{$\begin{array}{l}\text { The relationship between specialists in the cosmetics industry requires some level of trust. This item } \\
\text { focuses on variations of this, including swift trust. }\end{array}$} \\
\hline 18 & Acquisition of Innovative Units & Efficiency - people's attitudes towards learning \\
\hline $\begin{array}{l}\text { Literature } \\
\text { Review }\end{array}$ & $\begin{array}{l}\text { (Cassiman \& Veugelers, 2006; Granstrand, et al., } \\
\text { 1992; Rice, 1994) }\end{array}$ & $\begin{array}{l}\text { (Argyris \& Schön, I978; Bessant \& Tsekouras, } \\
\text { 200 I; Brady \& Davies, 2004;W. Cohen \& Levin- } \\
\text { thal, I989;W. Cohen \& Levinthal, I990; Fernan- } \\
\text { dez-Breis, et al., 2009; J. Hagedoorn \& Duysters, } \\
\text { 2002; Pérez-Nordtvedt, Kedia, Datta, \& Rasheed, } \\
\text { 2008) }\end{array}$ \\
\hline Synthesis & \multicolumn{2}{|c|}{$\begin{array}{l}\text { By innovative units this item considers not only the acquisition of new physical departments but the } \\
\text { creation of new teams that can contribute efficiently towards learning. }\end{array}$} \\
\hline 19 & Internal R\&D x External R\&D & $\begin{array}{l}\text { Scope - The greater, the harder for the com- } \\
\text { petitor to copy }\end{array}$ \\
\hline $\begin{array}{l}\text { Literature } \\
\text { Review }\end{array}$ & $\begin{array}{l}\text { (Arnott \& Pervan, 2005; Baum, Calabrese, \& } \\
\text { Silverman, 2000; Cassiman \& Veugelers, 2006; Ce- } \\
\text { ladon, 2007; H. Chesbrough, 2003b, 20I I; H. a.V. } \\
\text { Chesbrough, Wim and West, Joel, 2006c; Henry } \\
\text { William Chesbrough, 2003a, 2007; Henry W. Ches- } \\
\text { brough \& Appleyard, 2007; Freeman, I987; Glaude, } \\
\text { 2006; Granstrand, et al., 1992; John Hagedoorn \& } \\
\text { Schakenraad, I994; Howells, 1996; Lane \& Lubatkin, } \\
\text { I998; Nikulainen, 2008; Rothwell, 1994) }\end{array}$ & $\begin{array}{l}\text { (Chandler, 1990;Van De Vrande, Vanhaverbeke, } \\
\text { \& Gassmann, 2010) }\end{array}$ \\
\hline
\end{tabular}




\begin{tabular}{|c|c|c|}
\hline Synthesis & \multicolumn{2}{|c|}{$\begin{array}{c}\text { The greater and more complex mix of internal and external R\&D strategies, the harder for the } \\
\text { competitor do copy. }\end{array}$} \\
\hline 20 & $\begin{array}{c}\text { Technology Scanning (putting ideas into practice } \\
\text { to create value). }\end{array}$ & $\begin{array}{c}\text { Flexibility - Capacity to build one innovation } \\
\text { initiative on the top of another }\end{array}$ \\
\hline Literature & $\begin{array}{c}\text { Arnott and Pervan 2005; Cassiman and Veu- } \\
\text { gelers 2006; Glaude 2006; Chesbrough 2006c; } \\
\text { Celadon 2007; Chesbrough 2007; Chesbrough and } \\
\text { Appleyard 2007; Nikulainen 2008; Chesbrough } \\
20 I \text { I) }\end{array}$ & $\begin{array}{c}\text { (Bird, Osland, Mendenhall, \& Schneider, I999; } \\
\text { Eisenhardt \& 2002) }\end{array}$ \\
\hline Synthesis & \multicolumn{2}{|c|}{$\begin{array}{c}\text { Firms should be capable and flexible enough to build innovative ideas by scanning technology and } \\
\text { people's capabilities (absorptive capacity) }\end{array}$} \\
\hline
\end{tabular}

Table I Conceptual framework - Relating $\mathrm{OI}$ and $\mathrm{KI}$ with the reviewed literature 


\section{Research Strategy - The Case Study}

This research aims to make an analysis that will be carried out within an industrial environment, the cosmetics sector in Brazil. The focus of the research is on the firms' ability to integrate knowledge under the influence of different degrees of innovation openness, exploring the interaction of the main actors in this process. So, a qualitative research is employed, as the context is very important and should therefore be analysed. Multiple case studies will allow replication of responses to the research, or will allow the description of circumstances where responses are not replicated (Yin, 1994). One of the participating organisations will be used as a pilot case (Yin, 1994) enabling the refinement of aspects of the research such as interview schedules, interview questions and interview techniques. This pilot was carried out in Brazil as an attempt to refine the instrument of collection of data within the socio-cultural environment of this study. Choosing one specific sector such as the cosmetics sector, facilitates the validation of the research in its final stages, as the design of this study uses a replication approach, that is, each individual case study consists of a "whole" study, in which convergent evidence is sought regarding the facts and conclusions for the case; each case's conclusion are then considered to be the information needing replication by other individual cases (Yin, 2009). The choice of cosmetics industry is also relevant as research in this industry is still incipient. Research data was collected from multiple sources in each case. This allows for triangulation of data sources (Yin, 1994) in order to confirm, or discon- firm, answers to the research questions. Observing activities in loco, interviewing professionals, and analysing secondary data were employed as methods to collect data. Semistructured interviews were selected as the primary data collection method for this study.

\section{Collection of empirical data}

A preliminary collection of data was done using a Likert questionnaire, which was applied in every company before the interviews. It was designed to discover the positioning of each firm in a scale, from "more traditional" (closed) innovator to "more open" innovator. The results helped to improve the ideas to be used during interviews. As a result of this initial study, I was able to refine the data collection instrument.

Comparing the preliminary results with the analysis, it can be concluded that firms NA, RA are "more open", $B U, B T, L C$ and CA are "hybrid" and AL, HN, BN are "more traditional".

The questionnaire (phase I) was created based on both concepts, $\mathrm{Ol}$ and $\mathrm{KI}$, and one person of each firm answered it, normally a director of technology / innovation or CEO in large firms, and general managers (owners) of SMEs. The rationale behind this approach was based on the fact that this study proposes a comparison between more open and more closed firms. Therefore, it was decided to check if there was reasonable level of difference in openness, at least between

\begin{tabular}{|l|l|l|l|l|l|l|l|l|l|}
\hline & $\begin{array}{l}\text { More } \\
\text { Open }\end{array}$ & Hybrid & $\begin{array}{l}\text { More } \\
\text { Closed }\end{array}$ & & & & & & \\
\hline Firm & NA & BT & BU & RA & LC & CA & AL & HN & BN \\
\hline Size & Large & Large & Medium & Large & Small & Small & Medium & Small & Medium \\
\hline Location & $\begin{array}{l}\text { São } \\
\text { Paulo }\end{array}$ & $\begin{array}{l}\text { Curiti- } \\
\text { ba }\end{array}$ & Curitiba & $\begin{array}{l}\text { Curiti- } \\
\text { ba }\end{array}$ & $\begin{array}{l}\text { Curiti- } \\
\text { ba }\end{array}$ & $\begin{array}{l}\text { Curiti- } \\
\text { ba }\end{array}$ & Curitiba & Manaus & Curitiba \\
\hline Degrees of Openness & MORE OPEN & \multicolumn{10}{|c|}{ HBRRID } \\
\hline
\end{tabular}

Table 9 Firms divided by degrees of openness (Phase I) / * Data from preliminary questionnaire only

\begin{tabular}{|c|c|c|c|c|c|c|c|c|c|}
\hline $\begin{array}{c}\text { Total of Open In- } \\
\text { novation Relating } \\
\text { Practices }\end{array}$ & 38 & 33 & 20 & 31 & 12 & 15 & 7 & 6 & 9 \\
\hline SAMPLE FIRMS & NA & BT & BU & RA & LC & CA & AL & HN & BN \\
\hline Openness & \multicolumn{2}{|c|}{ More Open } & \multicolumn{4}{|c|}{ Hybrid } \\
\hline
\end{tabular}

Table 23 - Total of Open Innovation Relating Practices (Phase 2)

ISSN: 07 I8-2724. (http://www.jotmi.org)

Journal of Technology Management \& Innovation (c) Universidad Alberto Hurtado, Facultad de Economía y Negocios. 
some of the chosen firms. Even though the methodology does not intend to generalize the results, it was preferred to choose a varied sample to enrich the study. The second and most important part of the analysis (phase 2), that is, the application of semi-structured interviews, had to be compared with previous data obtained on the questionnaires, in search for possible discrepancies between both methods. Only large firms use project-based strategies to integrate knowledge, and SMEs rely more on informality. The share of common knowledge is more common between those professionals with similar academic degrees, particularly in pharmacy, biology or chemistry. However, some degree of rigidities can be noticed when sharing knowledge between different departments.

Collaboration across areas and disciplines is also more common in large firms, in particular when it is an international collaboration. SMEs concentrate knowledge in few people and normally the owner has got a lot of power when it comes to decision making. Important studies in the field points to a dialogical approach, trying to understand how face-to-face dialogues result in new organizational knowledge, "the dialogical of utterances per se is an important mechanism through which cognitive change and, thus, new knowledge may come about" (Tsoukas, 2009, p.942).

Brazil's national education levels are still behind its recent economical development causing shortage of specialized and technical labour. So, firms need to invest heavily in internal training policies in order to overcome the limitations of the market.
There are few suppliers of chemicals that are used in cosmetics, normally large multinational firms (i.e. Givaudan) established in Brazil. This creates an interesting characteristic to the sector as competing cosmetics firms rely on these few suppliers. Therefore, vertical collaboration is a modus operandi in this sector, and trust becomes essential. So, technological integration (external) requires competences of firms to be linked with technologies offered externally so they can assimilate and replicate this knowledge gained from external sources. This external knowledge "cannot simply be acquired by reactively scanning the existing pool of available technical information" (lansiti \& Clark, 1994 ,p.57I). Horizontal collaboration is more common among large firms that are supported by their own lawyers to deal with intellectual property issues for example. Company NA has created its own department for academic relations where an employee's expertise is dedicated to its interaction with universities and research institutes. Also, all firms without exception are implementing internal training in some degree. Large firms tend to focus on international trends, whereas SMEs are more concerned with quality assurance programs. This is in line with some ideas from researchers who said that "internal knowledge or technical capabilities remain crucial in determining firms' innovative capabilities and financial performance even when firms divert their attention more and more towards external knowledge" (Vanhaverbeke, et al., 2007, pp. ,p.2).

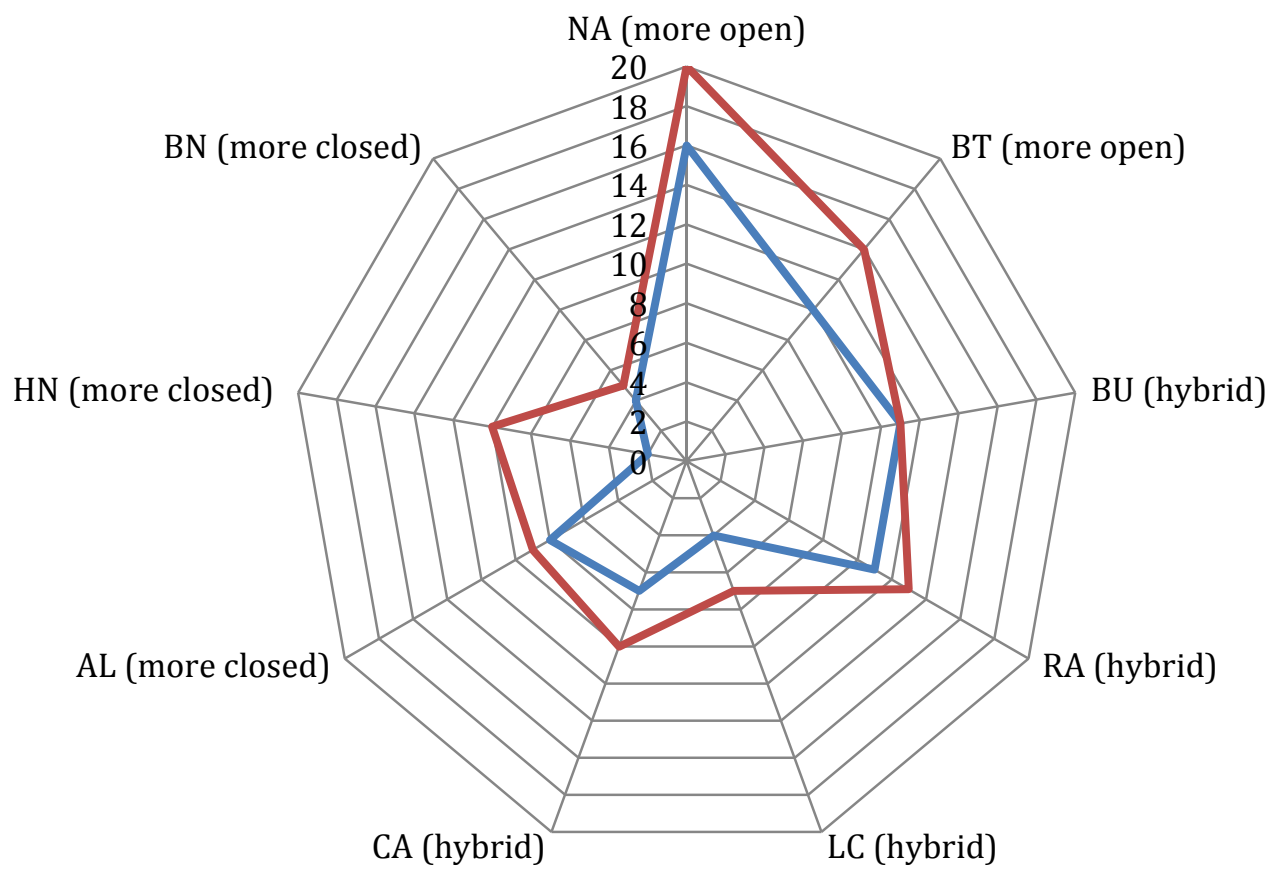

Open Innovation Knowledge Integration

Figure 2 - Radial graph comparing results from more open, hybrid and more closed firms

ISSN: 07 I8-2724. (http://www.jotmi.org)

Journal of Technology Management \& Innovation (c) Universidad Alberto Hurtado, Facultad de Economía y Negocios. 
SMEs, as in large firms, also combine knowledge in different and specific manners. BU's main source of external knowledge is a group of therapists spread all over Brazil. As LC was originated from a large firm to become its main supplier of soaps, it has developed an almost 'symbiotic' process of knowledge integration with this firm. Recently the firm is developing new strategies in order to 'break free' from this. So, the firm has begun to scan market needs that are not fulfilled by its main client firm. CA concentrates its efforts in certified organic cosmetics and obtains knowledge from developed countries, even though its raw materials are nationally grown. The integration of knowledge occurs mostly at administrative level, particularly because the firm has been created in an incubator and sponsored by government agencies. Finally, BN is a manufacturer of hair colouring products that compete 'head to head' with multinationals such as L'Oreal. The firm is clearly driven by strong marketing campaigns and publicity in the media.

\section{Conclusion}

This cross-case analysis has been carried out to compare different conditions of openness and the implication of these on knowledge integration, as well as its influence in innovation.

Firm size appeared as an important factor because of the high costs and increased complexity involved the Ol practices. Large case firms demonstrated an advantage in building processes that enable OI.Also, these firms have the ability to launch new products faster than SMEs due to their advantageous financial status that allow for large investments in marketing and publicity.Apart from that, large firms normally have their own laboratories and can compete with multinational in category 2 products, a higher regulated category of cosmetics that SMEs have difficulties to produce.

The preliminary questionnaire applied in the phase I of data collection resulted in two 'more open' firms, four 'hybrid' and three 'more traditional' in the nine case firms. This suggested that all firms, more open, hybrid and more traditional carried out open practices to a certain degree. During phase 2 of the data collection, thirty three interviews were carried out among the nine case firms. Results corroborated to a certain degree with the preliminary questionnaire (phase I). The results reveal that more open firms were also more intensively practicing knowledge integration, and that a degree of proportionality is also present between the two categories, that is, openness and knowledge integration, with the exception of the firm BU, a hybrid firm, whose practices are much more traditional comparatively.
Finally, all firms demonstrated a considerably high level of intensity in knowledge integration practices. Knowledge acquired externally is normally 'ordered' by internal needs and strategic direction.

\section{Implication for Management theories}

This study contributed to the expansion of the two concepts chosen as the theoretical basis of this study, Open Innovation and Knowledge Integration, exploring the relationship between these two concepts. It can be summarized that, based on these findings, the theory of innovation management that focuses on open innovation and the theory that focuses on knowledge integration could be extended and further compared in future studies.

The analysis and interpretation of results confirmed the existence of a relationship between these concepts, and a variation of intensity of related practices that suggests some sort of direct proportionality between them. Also, more open firms demonstrated higher levels of intensity in knowledge integration practices. Knowledge acquired externally is normally 'ordered' by internal needs and strategic direction, and it is a practice that is present in every case firm.

\section{Policy}

Government policies are pushing economic growth by using sectoral strategies. Sustainability and environmental issues are amongst the most important ones in the cosmetics sector, and actions have been taken to minimize the impact that industries can cause. In spite of the efforts made by the Brazilian authorities, there is still a huge gap between economic development and educational development in the country.

A huge technological gap has been seen in the study between large (medium) and small firms, corresponding to the categories of cosmetics I and 2. These differences also caused a 'knowledge gap' between these firms, because those working with high-tech materials or category 2 products also utilize high calibre workers that deal with higher complexity. Small firms, normally making category I products, tend to contract ad-hoc specialists in specific situations and occasions, and this can present difficulties in terms of competitiveness. As technology is not the only differentiator in this sector, small firms make use of niche marketing tools (i.e. organic products) that do not depend on high technology but still cause an impact to a certain group of consumers.

Brazil's socio-economic situation has arguably played an important role in the growth of cosmetics consumption in recent years, and it is to be considered and further observed in similar research. 


\section{Limitation of this Study}

This research has focused on a cluster of the cosmetics industry in the southern part of Brazil. This has to be taken into consideration in order to avoid generalizations that might not reflect the true when research is to be done outside this region. The cosmetics sector has got particularities that are totally different to information technology and other high-tech sectors. For this reason, findings of this study should not be replicated in other similar industries that follow comparable regulations.

There have been important developments in the literature of $\mathrm{KI}$ such as studies on knowledge flows (Volberda, et al., 20I0), focus on firm-internal knowledge (Koch, 20II), on tacit knowledge (Hong, Suh, \& Koo, 20II) and on microdynamics (Strambach \& Klement, 20I2) amongst others. This indicates that future research in $\mathrm{KI}$ can benefit from more developed concept that probably offers more nuanced understanding for researchers.

\section{Further Research}

This study is the first attempt in comparing open innovation and knowledge integration concepts in the cosmetics industry, aiming to contribute with Resource (RubensteinMontano, et al.) Based View theories. Most research done previously was concentrated in high technology firms in other sectors mainly related to information technology or biotechnology. So, the differential created by this research can offer new possibilities for research in this area by showing characteristics of a medium-technology industry in a developing country.

Future studies could improve the understanding of interfirm relationship in the sector and the consequences of this for innovation. The relationship between these concepts has been confirmed as interdependent and it is mediated by variables such as age, size, product category, distribution, orientation of integration (vertical versus horizontal) and technological base.

\section{References}

ACHA, V. (2006). Open by design: the role of design in open innovation. doi: I0.5465/ambpp.2008.336532I0

AHUJA, G. (2000). Collaboration Networks, Structural Holes, and Innovation: A Longitudinal Study. Administrative Science Quarterly, 45(3), 425-455. doi: 10.2307/2667।05

ALLIO, R. J. (2005). Interview with Henry Chesbrough: Innovating innovation. Strategy and Leadership, 33(I), 19-24. doi: I0.1 108/10878570510572617

AMIN,A., \& Cohendet, P. (2004).Architectures of knowledge. doi: 10.1007/s 10997-006-9012-3

ANDERSSON, U., Holm, D. B., \& Johanson, M. (2006). Moving or doing? Knowledge flow, problem solving, and change in industrial networks. Journal of Business Research, 60, 32-40. doi: 10.1016/j.jbusres.2006.09.010

ARGYRIS, C., \& Schön, D. (1978). Organizational Learning. doi: $10.1177 / 017084068000100310$

ARNOTT, D., \& Pervan, G. (2005). A critical analysis of decision support systems research. Journal of Information Technology, 20, 67-87. doi: 10.1057/palgrave.jit.2000035

BAUM, J.A. C., Calabrese, T., \& Silverman, B. S. (2000). Don't Go It Alone: Alliance Network Composition and Startups' Performance in Canadian Biotechnology. Strategic Management Journal, 2I(3), 267-294. doi: 10.1002/(sici) I0970266(200003)2।:3\%3C267::aid-smj89\%3E3.0.co;2-8

BENGTSSON, L., Bergek, A., Berggren, C., \& Söderlund, J. (2009). Exploring knowledge integration and innovation. doi: 10.1093/acprof:oso/9780199693924.003.000 I

BENGTSSON, L., Niss, C., \& von Haartman, R. (2008). Being Both Master and Apprentice: Promoting Knowledge Integration in a Distributed Industrialisation Process? R\&D Management Advanced Workshop. doi: 10.1III/j.I4678691.2010.00578.x

BESSANT, J., \& Tsekouras, G. (200I). Developing Learning Networks. Al \& Society, 15, 82-98. doi: I0. 1007/bf0 I 205739

BIRD, A., Osland, J. S., Mendenhall, M., \& Schneider, S. C. (1999). Adapting and Adjusting to Other Cultures:What We Know but Don't Always Tell. Journal of Management Inquiry, 8(2), I52-I65. doi: I0. I 177//05649269982009 
BIRKINSHAW, J., Bessant, J., \& Delbridge, R. (2007). Finding, Forming and Performing: Creating Networks for Discontinuous Innovation. California Management Review, 49(3), 67-84. doi: 10.2307/41166395

BLACKLER, F. (2002). Knowledge, Knowledge Work and Organizations. The strategic management of intellectual capital and organizational knowledge, 47-62. doi: 10.1016/b978-07506-7475-I.50006-3

BRADY, T., \& Davies, A. (2004). Building Project Capabilities: From Exploratory to Exploitative Learning. Organization Studies, 25(9), I60I-I62I. doi: I0.1 I 77/0I 70840604048002

BROWN, J. S., \& Duguid, P. (1991). Organizational Learning and Communities-of-Practice:Toward a Unified View of Working, Learning and Innovation. Organization Science, 2(I), 40-57. doi: 10.1287/orsc.2.I.40

BRUNER, J. S. (1990). Acts of Meaning. doi: 10.1017/ s003329I700030555

CARLILE, P. R. (2002). A Pragmatic View of Knowledge and Boundaries: Boundary Objects in New Product Development. Organization Science, I3(4), 442-455. doi: I0.1287/ orsc.13.4.442.2953

CASSIMAN, B., \& Veugelers, R. (2006). In Search of Complementarity in Innovation Strategy: Internal R\&D and external knowledge acquisition. Management Science, 52(I), II69I I84. doi: I0.1287/mnsc. 1050.0470

CELADON, K. L. (2007). Knowledge Share Management:The Case of a Brazilian High-tech Company. Paper presented at the EURAM 2007, Paris.

CHANDLER, A. D., Jr. (1990). Scale and scope: the dynamics of industrial capitalism. doi: 10.1 I26/science.248.4963.1667

CHESBROUGH, H. (2003b). The era of open innovation. MITSloan Management Review, 44(3), 35-4I. doi: 10.2307/4II664I6

CHESBROUGh, H. (20II). Open Services Innovation: Rethinking your business to grow and compete in a new era. doi: 10.1007/978-88-470-1980-5_II

CHESBROUGH, H., \& Crowther, A. K. (2006). Beyond high tech: early adopters of open innovation in other industries. R\&D Management, 36(3), 229-236. doi: 10.1III/j.1467$9310.2006 .00428 . x$
CHESBROUGH, H. a. V., Wim and West, Joel. (2006c). Open Innovation - Researching a New Paradigm. 373. doi: | 0. I | | |/j. |467-869|.2008.00502.x

CHESBROUGH, H.W. (2003a). Open Innovation. The New Imperative for Creating and Profiting from Technology. 227. doi: I0.5465/amp.2006.2059I0I4

CHESBROUGH, H.W. (2007). Why Companies Should Have Open Business Models. MITSloan Management Review, 48(2), 22-28. doi: 10.2307/4| I66349

CHESBROUGH, H.W., \& Appleyard, M. M. (2007). Open Innovation and Strategy. California Management Review, 50(I). doi: $10.2307 / 4 \mid 166416$

CHIVA, R. a. A., Joaquín. (2005). Organizational Learning and Organizational Knowledge: Towards the Integration of Two Approaches. Management Learning, 36(I), 49-68. doi: I0.1 I77// 350507605049906

CHRISTENSEN, J. F., Olesen, M. H., \& Kjær, J. S. (2005). The Industrial Dynamics of Open Innovation - Evidence from the Transformation of Consumer Electronics. Research Policy, 34, I533-1549. doi: 10.1016/j.respol.2005.07.002

CLARK, K. B., \& Wheelwright, S. C. (1993). Managing new product and process development: text and cases. doi: 10.1016/0737-6782(93)90069-3

COCKBURN, I. M., \& Henderson, R. M. (1998). Absorptive Capacity, Coauthoring behavior, and the organization of research in drug discovery. Journal of Industrial Economics, 46(2), I57- |82. doi: 10.1 I I I/|467-645I.00067

COHEN, S. I., \& Allen, T. J. (1969). Information flow in research and development laboratories. Administrative Science Quarterly, I4(I), I2-19. doi: 10.2307/2391357

COHEN,W., \& Levinthal, D.A. (1989). Innovation and Learning Economic Journal. 99, 569-596. doi: I0.2307/2233763

COHEN,W., \& Levinthal, D.A. (1990). Absorptive capacity: a new perspective on learning and innovation. Administrative Science Quarterly, 35, I28-152. doi: 10.2307/2393553

COOK, S. D. N., \& Brown, J. S. (1999). Bridging Epistemologies:The Generative Dance Between Organizational Knowledge and Organizational Knowing. Organizational Science, I0(4), I0. doi: 10.1287/orsc. 10.4.38।

COOK, S. D. N. a. D. Y. (1993). Culture and organizational learning. Journal of Management Inquiry, 2(4), 373-390. doi: I0.1177/105649269324010 
CRISCUOLO, P., \& Nesta, L. (2008). Horizontal and vertical knowledge integration in Chemical and Pharmaceutical Research. Schumpeter Society Conference 2008. doi: 10.2298/ jsc0803307p

DAHLANDER, L., \& Gann, D. (2007). How open is innovation? DRUID Summer Conference 2007. doi: I0.4337/978|84844|248.00009

DEFILLIPPI, J. R., Arthur, Michael B. and Lindsay, Valerie J. (2006). Knowledge at Work: Creative Collaboration in the Global Economy. doi: I0.1 I I I/j. I467-93 I0.2007.00475_2.x

DOSI, G., Faillo, M., \& Marengo, L. (2008). Organizational capabilities, patterns of knowledge accumulation and governance structures in business firms: An introduction. [Article]. Organization Studies, 29(8-9), II65-II85. doi: 10.1 I77/0170840608094775

DOUGHERTY, D. (1992). Interpretive barriers to successful product innovaotion in large firms. Organization Science, 3(2), 179-202. doi: 10.1287/orsc.3.2.179

EASTERBY-SMITH, M., A. Lyles, M., \& Tsang, E. W. K. (2008). Inter-Organizational Knowledge Transfer: Current Themes and Future Prospects. Journal of Management Studies, 45(4), 677-796. doi: I0.1 I I //j. 1467-6486.2008.00773.x

EASTERBY-SMITH, M., \& Prieto, I. M. (2008). Dynamic Capabilities and Knowledge Management: an Integrative Role for Learning? British Journal of Management, 19, 235-249. doi: I0.1 I I I/j. I467-855 I.2007.00543.x

EISENHARDT, K. M., \& Okhuysen, G.A. (2002)., \& , 370-386. (2002). Integrating knowledge in groups: How formal interventions enable flexibility. Organization Science, 13(4), 370386. doi: 10.1287/orsc. 13.4.370.2947

ENBERG, C. (2007). Knowledge Integration in Product Development Projects. Faculty of Arts and Sciences, Doctor, 234. doi: |0. I093/oxfordhb/9780 | $99563 \mid 42.003 .0020$

ERNST, H., \& Kohn, S. (2007). Organizational Culture and Fuzzy Front End Performance. Innovation Management, 2(Special), I- |8. doi: I0. I I I/j. I467-869| .2009.00526.x

ETZIONI, A. (1996). The responsive community: A communitarian perspective. American Sociological Review, 6I(I), I-12. doi: 10.2307/2096403
FERNANDEZ-BREIS, J.T., Castellanos-Nieves, D., \& ValenciaGarcia, R. (2009). Measuring individual learning performance in group work from a knowledge integration perspective. [Article]. Information Sciences, 179(4), 339-354. doi: 10.1016/j.ins.2008.10.014

FLOWERS, S. (2007). The importance of perspective: exploring implications of user-centric innovation. doi: 10.4018/978I-59904-558-0.ch007

FLOWERS, S. (2008). The New Inventors: How users are changing the rules of innovation. [Research Report]. 44. doi: |0.755|/978-0-262-3|709-2-ch I79

FLOWERS, S., \& Henwood, F. (2010). Perspectives on User Innovation (Vol. 16). London: Imperial College Press.

FREEMAN, C. (1987). Technology policy and economic performance: Lessons from Japan. doi: 10.1016/0048$7333(88) 9001 \mathrm{I}-\mathrm{x}$

GANN, D. M. (2005). H. Chesbrough, Open Innovation: the new imperative for creating and profiting from technology. Research Policy, 34(I), 122-I23. doi: 10.5172/ impp.2004.6.3.474

GASSMANN, O. (2006). Opening up the innovation process: towards an agenda. R\&D Management, 36(3), 223-228. doi: I0.1 I I I/j. I 467-9310.2006.00437.x

GASSMANN, O., \& Enkel, E. (2004). Towards a Theory of Open Innovation: Three Core Process Archetypes. R\&D Management Conference (RADMA). doi: $10.11 \mathrm{l} / \mathrm{j}$.1467$9310.2010 .00605 . x$

GHERARDI, S.a.D. N. (2002). Learning the trade: a culture of safety in practice. Organizational Science, 9(2), 191-223. doi: I0.1177//350508402009002264

GLAUDE, M. (2006). Science, technology and innovation in Europe. doi: 10.1093/her/18.1.122

GRANOVETTER, M. S. (1973). The strenght of weak ties. American Journal of Sociology, 78(6), I360-I380.

GRANSTRAND, O., Bohlin, C., Oskarsson, C., \& Sjöberg, N. (1992). External technology acquisition in large multinational firms. R\&D Management, 22(2), I I I- I33. doi: 10.1 I I I/j. I4679310.1992.tb0080I.x

GRANT, R.M.(1996a).Prospering in dynamically-competitive environments - organizational capability as knowledge integration. Organization Science, 7(4), 375-387. doi: 10.1287/ orsc.7.4.375 
GRANT, R. M. (1996b). Toward a Knowledge-Based Theory of the Firm. Strategic Management Journal, 17, 109-122. doi: I0.1002/smj.425017III 0

GRANT, R. M. (1997). The knowledge-based view of the firm: Implications for management practice. Long Range Planning, 30(3), 450-454. doi: I0.10I6/s0024-630I(97)00025-3

GULATI, R., Nohria, N., \& Zaheer, A. (2000). Strategic Networks. Strategic Management Journal, 2I(3), 203-2I5. doi: $\quad$ 10.1002/(sici) 1097-0266(200003)21:3\%3C203::aidsmj I02\%3E3.0.co;2-k

HAGEDOORN, J., \& Duysters, G. (2002). Learning in dynamic inter-firm networks - the efficacy of quasi-redundant contacts. Organization Studies, 23(4), 525-548. doi: 10.1177/0170840602234002

HAGEDOORN, J., \& Schakenraad, J. (1994). The Effect of Strategic Technology Alliances on Company Performance. Strategic Management Journal, I5(4), 29I-309. doi: I0.1002/ smj.4250I50404

HATCHUEL, A., Le Masson, P., \& Benoît, W. (2002). From Knowledge Management to Design-Oriented Organisations. International Social Science Journal, 54(I7I), 25-37. doi: I0.1III/|468-245I.00356

HAVENS, C., \& Knapp, E. (1999). Easing into knowledge management Strategy and Leadership 27(2), 4-9. doi: 10.II08/ eb054629

HAWKINS, D. I., Best, R. J., \& Coney, K.A. (1995). Consumer behaviour. doi: 10.1016/s0737-6782(96)90163-0

HIENERTH, C. (2006). The commercialization of user innovations: the development of the kayak rodeo industry. R\&D Management, 36(3), 273-294. doi: 10.1III/j.14679310.2006.00430.x

HISLOP, D., Newell, S., Scarbrough, H., \& Swan, J. (2000). Networks, knowledge and power: Decision making, politics and the process of innovation. Technology Analysis \& Strategic Management, I2(3), 399-4I I. doi: I0.1080/7I 3698478

HONG, D., Suh, E., \& Koo, C. (20I I). Developing strategies for overcoming barriers to knowledge sharing based on conversational knowledge management: A case study of a financial company. Expert Systems with Applications, 38(I2).

HOON OH, C., \& Rugman, A. M. (2006). Regional Sales of Multinationals in the World Cosmetics Industry. European Management Journal, 24(2-3), I63-173. doi: 10.1016/j. emj.2006.03.006
HOWELLS, J. (1996). Tacit Knowledge, Innovation and Technology Transfer. Technology Analysis \& Strategic Management, 8(2), 9l. doi: 10.1080/09537329608524237

HUANG, J. C., \& Newell, S. (2003). Knowledge integration processes and dynamics within the context of cross-functional projects. International Journal of Project Management, 2I(3), I67-I 76. doi: I0.1016/s0263-7863(02)0009I-I

IANSITI, M., \& Clark, K. B. (I994). Integration and dynamic capability: evidence from product development automobiles and mainframe computers. Industrial and Corporate Change, 3(3), 557-605. doi: 10.1093/icc/3.3.557

$\mathrm{KOCH}, \mathrm{A} .(20 \mathrm{II})$. Firm-internal knowledge integration and the effects on innovation. Journal of Knowledge Management, 15(6), 984-996.

KODAMA, M. (2009). Boundaries Innovation and Knowledge Integration in the Japanese Firm. Long Range Planning, 42, 463-494. doi: I0.10 I6/j.Irp.2009.08.00 I

KOGUT, B. (2000). The Network as Knowledge: Generative Rules and the Emergence of Structure. Strategic Management Journal, 2I(3), 405-425. doi: 10.1002/(sici) 10970266(200003)2।:3\%3C405::aid-smj 103\%3E3.0.co;2-5

KUMAR, S. (2005). Exploratory analysis of global cosmetic industry: major players, technology and market trends. Technovation, 25(1I), 1263-1272. doi: 10.1016/j.technovation.2004.07.003

KUMAR, S., Massie, C., \& Dumonceaux, M. D. (2006). Comparative innovative business strategies of major players in cosmetic industry. Industrial Management and Data Systems, I06(3), 285-306. doi: DOI I0.I 108/026355706/065346 I

LAM, A. (2000). Tacit Knowledge, Organizational Learning and Societal Institutions: An Integrated Framework. Organization Studies (Walter de Gruyter GmbH \& Co. KG.), 2 I (3), 487. doi: I0.I I77/0I 708406002 | 300 I

LANE, P. J., \& Lubatkin, M. (1998). Relative Absorptive Capacity and Interorganizational Learning. Strategic Management Journal, 19(5), 46I-477. doi: 10.1002/(sici) I0970266(I99805) | 9:5\%3C46|::aid-smj953\%3E3.3.co;2-c

LAURSEN, K., \& Salter, A. (2005). The paradox of openness: apropriability and the use of external sources of knowledge for innovation. doi: 10.1016/j.respol.2013.10.004

LAURSEN, K., \& Salter, A. (2006). Open for Innovation: The Role of Openness in Explaining Innovation Performance Among U.K. Manufacturing Firms. Strategic Management Journal, 27(2), I3I-I50. doi: I0.1002/smj.507 
LAWRENCE, P. R., \& Lorsch, J.W. (1967). Differentiation and Integration in Complex Organizations. Administrative Science Quarterly, I2(I), I-47.

LEHRER, K. (1987). Personal and social knowledge. Social epistemology, 73(I), 87-I07.

LEONARD, D., \& Sensiper, S. (1998). The Role of Tacit Knowledge in Group Innovation. California Management Review, 40(3), I I2-I32. doi: \/0.2307/4| I65946

LEONARD-BARTON, D. (1992). The Factory as a Learning Laboratory. Sloan Management Review, 34(I), 23-38. doi: 10.1287/mnsc.34.10.1252

LINDEGAARD, S. (2010). The Open Innovation Revolution: Essentials, Roadblocks and Leadership Skills. doi: 10.1086/650250

LITTLER, C. R., Wiesner, R., \& Dunford, R. (2003). The dynamics of delayering: changing management structures in three countries. Journal of Management Studies, 40(2), 225256. doi: I0. I I I I/ |467-6486.00339

MCGUINNESS, T. (2008). Dynamic capabilities for entrepreneurship and innovation in marketing-driven organisations. The Seventh International Congress: Marketing Trends. doi: 10.1007/s | |365-0|4-0330-7

MEYER, M. H., \& Mugge, P. C. (200I). Make Platform Innovation Drive Enterprise Growth. Research-Technology Management, 44, 25-49.

MEYERSON, D., Weick, K., \& Kramer, R. (1996). Swift trust and temporary groups. Trust in organizations: Frontiers of theory and research, I66-195. doi: 10.4I35/978|4522436I0. n9

MINTZBERG, H., Jorgensen, J., Dougherty, D., \& Westley, F. (1996). Some Surprising Things About Collaboration-Knowing How People Connect Makes It Work Better. Organizational Dynamics, 25(I), 60-7I. doi: 10.1016/s0090$26|6(96) 9004|-8$

MOWERY, D. C. (1982). The relationship between contractual and intrafirm forms of industrial research in American manufacturing, 1900 - 1040. Explorations in Economic History, 20(4), 35I-374. doi: I0.1016/00 I4-4983(83)90024-4

MURMANN, J. P. (2003). Knowledge and Competitive Advantage:The Coevolution of Firms, Technology and National Institutions. doi: 10.1017/s00220507/0000495
MURRAY, F., \& O'Mahony, S. (2007). Exploring the foundations of cumulative innovation: Implications of Organization Science. Organization Science, 18(6), 1006-1021. doi: 10.1287/orsc. 1070.0325

N/EVESTAD, T.-O. (2008). Safety Cultural Preconditions for Organizational Learning in High-Risk Organizations. Journal of Contingencies and Crisis Management, 16(3), I54-202. doi: I0. I I I I/j.I468-5973.2008.00544.x

NIKULAINEN,T. (2008). Open Innovation and nanotechnology - an opportunity for traditional industries. doi: 10.1 142/ s02198770I250023x

NONAKA, I. a. T., David. (200I). Managing Industrial Knowledge. 344. doi: $10.1002 / \mathrm{kpm} .183$

NONAKA, I. a.T., H. (1995). The Knowledge Creating Company. doi: $|0.10| 7 /$ s $\mid 472669608000170$

OKHUYSEN, G. A., \& Eisenhardt, K. M. (2002). Integrating Knowledge in Groups: How Formal Interventions Enable Flexibility. Organization Science, 13(4), 370-386. doi: 10.1287/orsc.13.4.370.2947

PENROSE, E. (1959). The theory of the growth of the firm. New York: Oxford University Press.

PÉREZ-NORDTVEDT, L., Kedia, B. L., Datta, D. K., \& Rasheed, A. A. (2008). Effectiveness and Efficiency of Cross-Border Knoweldge Transfer: An Empirical Examination. Journal of Management Studies, 45(4), 7I4-744. doi: 10.1III/j.14676486.2008.00767.x

PERKMANN, M., \& Walsh, K. (2007). University-industry relationship and open innovation: towards a research agenda. International Journal of Management Reviews. doi: I0.1 II I/j. I 468-2370.2007.00225.x

PILANIA, R. K. (2006). State of Organizational Culture for Knowledge Management in Indian Industry. Global Business Review, 7(I), I I9-I35. doi: I0.I I77/0972 I5090500700 I08

PISANO, G. P. (1994). Knowledge, integration and the locus of learning: an empirical analysis of process development. Strategic Management Journal(I5 Winter Special Issue), 85100. doi: 10.1002/smj.4250I50907

POLANYI, M. (1958). Personal knowledge. doi: 10.1017/ s003329I700040204

POLANYI, M. (1967). The tacit dimension. New York: Doubleday \& Co. 
POWELL, W.W., Koput, K.W., \& Smith-Doerr, L. (1996). Interorganizational Collaboration and the Locus of Innovation: Networks of Learning in Biotechnology. Administrative Science Quarterly, 4I(I), I I6-I45. doi: I0.2307/2393988

RAVASI, D., \& Verona, G. (200I). Organising the process of knowledge integration: the benefits of structural ambiguity. Scandinavian Journal of Management, I7(I), 4I-66. doi: I0.1016/s0956-522I(00)00032-4

RICE, F. (1994). The new cosmetics industry makeup. Fortune, I30(9), I7. doi: I0. I0 I6/b978-044482654-I/5002 I-I

RINDOVA, V. P., \& Petkova, A. P. (2007). When is a new thing a good thing? Technological change, product form design, and perceptions of value for product innovations. Organization Science, I8, 217-232. doi: I0.1287/orsc. 1060.0233

RINGBERG, T., \& Reihlen, M. (2008). Towards a SocioCognitive Approach to Knowledge Transfer. Journal of Management Studies, 45(5), 9|3-935. doi: 10.11 I I/j.14676486.2007.00757.x

ROBERTS, J. (2006). Limits of Communities of Practice. Journal of Management Studies, 43(3). doi: 10.1 I I I/j. I4676486.2006.00618.x

ROTHWELL, R. (1994). Towards the fifth-generation innovation process. International Marketing Review, I I(I), 7. doi: |0.1|08/0265|3394|005749|

RUBENSTEIN-MONTANO, B., Liebowitz, J., Buchwalter, J., McCaw, D., Newman, B., Rebeck, K., \& Team, T. K. M. M. (200I). A systems thinking framework for knowledge management. Decision Support Systems, 31, 5-16. doi: 10.1016/ s0167-9236(00)00II6-0

SACKMANN, S.A. (1992). Culture and subcultures: an analysis of organizational knowledge. Administrative Science Quarterly, 37, I40-16I. doi: 10.2307/2393536

SAHOTA, P. S., \& Lemon, M. (2004). Organizational culture as a knowledge repository for increased innovative capacity. Technovation, 24, 483-498. doi: 10.1016/s01664972(02)00 I02-5

SAWHNEY, M., Wolcott, R. C., \& Arroniz, I. (2006). The 12 different ways for companies to innovate. MITSloan Management Review, 47(3), 75-8I. doi: I0.1 109/emr.2007.329139

SCHEIN, E. H., \& (1993). On dialogue, culture and organizational learning. Organizational Dynamics, 22, 40-5I. doi: 10.1016/0090-2616(93)90052-3
SCHUMPETER, J.A. (1934). The Theory of Economic Development. Cambridge, MA: Harvard University Press.

SCOTT, F., Stuart, D. G., Stephanie, J.W., \& Robert, N. (2003). Knowledge sharing: context, confusion and controversy. International Journal of Project Management, 2I(3), I77-I87. doi: 10.1016/s0263-7863(02)00092-3

SELZNICK, P. (1957). Leadership in Administration:A Sociological Interpretation. doi: 10.2307/2088633

SHIBATA, G., Tse, D., Vertinsky, I., \& Wehrung, D. (199I). Do Norms of Decision-Making Styles, Organizational Design and Management Affect Performance of Japanese Firms? An Exploratory Study of Medium and Large Firms. Managerial and Decision Economics, 12, I35-I46. doi: 10.1002/ mde.4090I 20207

SIMOES-BROWN, D. (2008). Corporate open innovation - if it's so good why isn't everyone doing it? , from http://www. nesta.org.uk/corporate-open-innovation

SÖDERLUND, J. (2010). Knowledge entrainment and project management: Approaching knowledge integration in complex R\&D.Academy of Management. doi: 10.1016/j.ijproman.2009.11.010

STRAMBACH, S., \& Klement, B. (2012). Cumulative and Combinatorial Micro-dynamics of Knowledge: The Role of Space and Place in Knowledge Integration. European Planning Studies, 20(I I), I843-1866.

SZULANSKI, G. (2000). The Process of Knowledge Transfer: A Diachronic Analysis of Stickiness. Organizational Behavior and Human Decision Process, 82(I), 9-27.

TEECE, D., \& Pisano, G. P. (1994). The dynamic capabilities of firms: an introduction. Industrial and Corporate Change, 3(3), 537-556. doi: 10.1093/icc/3.3.537-a

TEECE, D., Pisano, G. P., \& Shuen, A. (1997). Dynamic capabilities and strategic management. Strategic Management Journal, 18, 509-533. doi: 10.1002/(sici) 10970266(I99708) I8:7\%3C509::aid-smj882\%3E3.0.co;2-z

TELL, F. (20II). Knowledge Integration and Innovation: A Survey of the Field. In C. Berggren, A. Bergek, L. Bengtsson, M. Hobday \& J. Söderlund (Eds.), Knowledge Integration and Innovation: Critical challenges facing international technology-based firms (pp. 20-58). Oxford: Oxford University Press. 
TSEKOURAS, G. (2006). Gaining competitive advantage through knowledge integration in a European industrialising economy. Int. J. Technology Management, 36(I/2/3), I26-I 47. doi: 10.1504/ijtm.2006.009965

TSOUKAS, H. (2009).A Dialogical Approach to the Creation of New Knowledge in Organizations. Organization Science, 20(6), 94I-957.

TUSHMAN, M. L. (1977). Special Boundary Roles in the Innovation Process. Administrative Science Quarterly, 22(4), 587-605. doi: $10.2307 / 2392402$

TUSHMAN, M. L., \& Scanlan, T. J. ( $198 \mathrm{I}$ ). Boundary Spanning Individuals: Their Role in Information Transfer and Their Antecedents. Academy of Management Journal, 24(2), 289-305. doi: $10.2307 / 255842$

VAN DE VRANDE, V., Vanhaverbeke, W., \& Gassmann, O. (20I0). Broadening the scope of open innovation: Past research, current state and future directions. International Journal of Technology Management, 52(3-4), 23 I-235.

VANHAVERBEKE,W., Cloodt, M., \& van de Vrande,V. (2007). Connecting Absorptive Capacity and Open Innovation. doi: 10.2139/ssrn. 1091265

VOLBERDA, H.W., Foss, N. J., \& Lyles, M.A. (2010). Absorbing the Concept of Absorptive Capacity: How to Realize Its Potential in the Organization Field. Organization Science, $2 I(4), 93 \mid-95 I$.

VON HIPPEI, E. (1986). Cooperation between rivals: informal know-how trading. Research Policy (16), 291-302. doi: I0.1016/0048-7333(87)900I5-I

VON HIPPEL, E. (1988). The Sources of Innovation. doi: 10.1 126/science.243.4897.1497

VON HIPPEL, E. (2005). Democratizing Innovation: The Evolving Phenomenon of User Innovation. Journal für Betriebswirtschaft(55), 63-78. doi: I0. I007/s I | 30 I-004-0002-8

VON HIPPEL, E. (2007). Horizontal innovation networks - by and for users. Industrial and Corporate Change, 16(2), 293315. doi: $10.1093 / \mathrm{icc} / \mathrm{dtm} 005$

WALLIN, M.W., \& Von Krogh, G. (2010). Focus on the Integration of Knowledge. Organizational Dynamics, 39(2), I45154. doi: 10.1016/j.orgdyn.2010.01.010
WATSON, S., \& Hewett, K. (2006). A Multi-Theoretical Model of Knowledge Transfer in Organizations: Determinants of Knowledge Contribution and Knowledge Reuse. Journal of Management Studies, 43(2). doi: I0.1 I I I/j. I4676486.2006.00586.x

WEBER, J. M., \& Villebonne, J. C. (2002). Differences in purchase behavior between France and the USA: the cosmetic industry. Journal of Fashion Marketing and Management, 6(4), 396-407. doi: |0.1 108/| 36/20202/0448673

WENGER, E. (1998). Communities of Practice: Learning as a Social System. Systems Thinker. doi: 10.1007/978-I-84996133-2_7

WEST, J., \& Gallagher, S. (2006). Challenges of open innovation: the paradox of firm investment in open-source software. R\&D Management, 36(3), 3 I9-33 I. doi: 10.1 I I I/j. I467$9310.2006 .00436 . x$

WU,Y. (2009). China's Cosmetics Industry:An Analysis of SCP Model The 5th International Symposium for Corporate Governance, I and 2, I88-192. doi: I0.I 109/itime.2012.629|425

YANG, J. (2005). Knowledge integration and innovation: Securing new product advantage in high technology industry. The Journal of High Technology Management Research, 16, I2I-135. doi: 10.1016/j.hitech.2005.06.007

YIN, R. (1994). Case Study Research: Design and Methods. Beverly Hill: Sage.

YIN, R. (2009). Case Study Research: design and methods (4th ed.). California: Sage.

ZAHRA, S. A., \& George, G. (2002). Absorptive capacity: a review, reconceptualization, and extension. Academy of Management Review, 27(2), 185-203. doi: 10.5465/ amr.2002.6587995

ZARIFIAN, P. (1996). Travail et communication: essai sociologique sur le travail dans la grande entreprise industrielle. doi: |0.2307/332279| 